\title{
Apparent nutrient digestibility, growth performance and feed utilization of juvenile Nile tilapia, Oreochromis niloticus L., as influenced by stocking density and feeding frequency
}

\author{
O. M. Yousif
}

Fish \& Shrimp Farming Project, Abu Al Abyad, P.O. Box 372, Abu Dhabi, United Arab Emirates

\begin{abstract}
Experiments were carried out to study the effects of stocking density and feeding frequency on apparent nutrient digestibility, growth performance and feed utilization efficiency of tilapia, Oreochromis niloticus juveniles. Significantly higher $(\mathrm{P}<0.05)$ weight gain $(\%)$, specific growth rate (SGR \%/day), feed conversion ratio (FCR), protein efficiency ratio (PER), apparent nitrogen utilization (ANU \%) and carcass nitrogen deposition (CND mg/day) were achieved by the fish stocked at $0.5 / \mathrm{L}$ and receiving either 3 or 4 meals/day. Significantly lower growth performance was observed in all groups of fish fed twice/day. At all stocking densities tested, apparent digestibility coefficients (ADC) for protein were significantly better when the fish were fed 3 meals/day. In general the ADC values obtained in this experiment were low for all nutrients which may be attributed to the excreta collection method applied in this study
\end{abstract}

Key words: Oreochromis niloticus, apparent nutrient digestibility, growth performance, feed utilization efficiency, stocking density, feeding frequency

\section{قالبلية الهضم الالاهري المواد الغذائية والنمو وكاءة الستخدلم الغذاءفي ألسمك النابيا النيلي اليلفة .Oreochrmis niloticus L. تهت تأثير الكثلة العدية وتكرالمرل التغنية \\ عمرaمد يماف}

\author{
مشروع تربية الأسمك والرويلن، أبو البيض، صب. مr - أبوظبي، الإمارك العربية المتحة \\ ملغص: تمت درلسة قابلية الهضم الظاهري للمواد الغذلئية والنمو وكفاءة لمتخدلم المواد الغذائية في لمٔمك التلابيا اليافعة عند

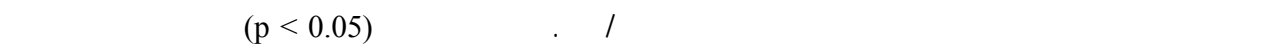

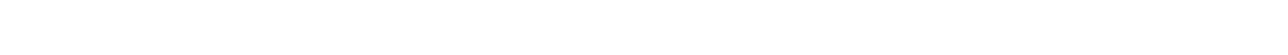

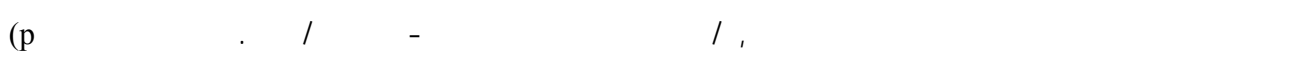

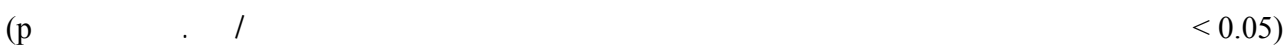

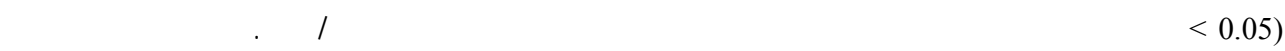

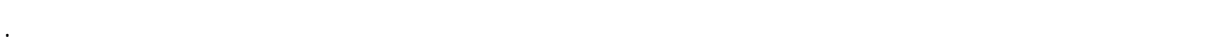 \\ كاملتففتلحية: التلابيا النيلي، قابلية الهضم الظاهري، النمو، كفاءة لمتخدلم الغذاء، الكثلة العددية، تكرار التغذية.
}

\section{Introduction}

Tilapia culture is an expanding industry throughout the world with the trend toward conversion to semi-intensive and intensive industry. The demand for studying the performance of fish under high-density conditions is intensifying. A crucial factor determining the feasibility of an aquaculture organism is the maximum 